\title{
FAKTOR-FAKTOR YANG BERPENGARUH TERHADAPAUDIT DELAY PADA BASIC INDUSTRY AND CHEMICALSYANG TERDAFTAR DI BURSA EFEK INDONESIA TAHUN 2013-2016
}

\author{
Yesika Christiani Br Ginting \\ Sabeth Sembiring
}

\begin{abstract}
Abstrak
Penelitian ini bertujuan untuk membuktikan secara empiris pengaruh Ukuran Perusahaan, Laba/Rugi Perusahaan, Ukuran KAP, Pergantian Auditor dan Opini Audit terhadap Audit Delay pada Basic Industry and Chemicals yang terdaftar di Bursa Efek Indonesia tahun 2013-2016. Rumusan masalah dalam penelitian ini adalah "Apakah Ukuran Perusahaan, Laba/Rugi Perusahaan, Ukuran KAP, Pergantian Auditor dan Opini Audit berpengaruh signifikan secara parsial maupun simultan terhadap Audit Delay?". Teknik pengambilan sampel yang digunakan adalah purposive sampling dengan jumlah sampel sebanyak 33 perusahaan. Data diperoleh dari Bursa Efek Indonesia tahun 20132016. Teknik analisis data yang digunakan adalah regresi linier berganda dengan tingkat signifikansi sebesar 5\%. Hasil uji secara parsial menunjukkan bahwa Ukuran Perusahaan dan Laba/Rugi Perusahaan berpengaruh negatif dan signifikan terhadap Audit Delay, Ukuran KAP berpengaruh positif dan sigifikan terhadap Audit Delay, Pergantian Auditor dan Opini Audit tidak berpengaruh terhadap Audit Delay. Hasil uji secara simultan menunjukkan bahwa variabel Ukuran Perusahaan, Laba/Rugi Perusahaan, Ukuran KAP, Pergantian Auditor dan Opini Audit berpengaruh terhadap Audit Delay. Kemampuan variabel independen dalam menjelaskan variabel dependen sebesar 14,3\% sedangkan sisanya sebesar $85,7 \%$ dijelaskan oleh variabel lain di luar mdel penelitian ini.
\end{abstract}

Kata kunci : Ukuran Perusahaan, Laba/Rugi Perusahaan, Ukuran KAP, Pergantian Auditor Opini Audit.

\section{PENDAHULUAN}

Audit Delay dapat dijelaskan menggunakan dua teori yaitu; Pertama, Teori Sinyal (Signalling Theory). Signalling menurut Bringham dan Houston (2006:39) adalah tindakan yang diambil oleh manajemen perusahaan dimana manajemen mengetahui informasi yang lebih lengkap dan akurat mengenai internal perusahaan dan prospek perusahaan di masa depan daripada pihak investor. Sinyal yang diberikan dapat dilakukan melalui pengungkapan informasi akuntansi seperti publikasi laporan keuangan. Umumnya pasar akan merespon informasi tersebut sebagai sinyal good news atau bad news. 
Kedua, Teori Kepatuhan (Compliance Theory). Tuntutan akan kepatuhan terhadap ketepatan waktu dalam penyampaian laporan keuangan tahunan perusahaan publik di Indonesia telah diatur dalam UndangUndang No. 8 Tahun 1995 tentang Pasar Modal, dan selanjutnya diatur dalam peraturan BAPEPAM. Peraturan-peraturan tersebut secara hukum mengisyaratkan adanya kepatuhan setiap perusahaan publik yang terlibat di pasar modal Indonesia untuk menyampaikan laporan keuangan tahunan perusahaan secara tepat waktu kepada BAPEPAM-LK. Hal tersebut sesuai dengan teori kepatuhan (compliance theory).

Saemargani (2015:2) menjelaskan bahwa ukuran perusahaan adalah besar kecilnya suatu perusahaan yang dilihat dari besar assetnya yang dimiliki oleh perusahaan tersebut. Ukuran perusahaan ditandai dengan beberapa ukuran antara lain, total penjualan, total asset, log size, jumlah pegawai, nilai pasar perusahaan, dan nilai buku perusahaan.

Menurut Islahuzzaman (2012:244), laporan laba/rugi (income statement) adalah laporan yang menyajikan informasi tentang hasil usaha perusahaan selama periode tertentu. Subekti dan Widiyanti dalam Iskandar dan Trisnawati (2010:178) menyatakan ada beberapa alasan yang mendorong terjadinya kemunduran laporan publikasi, yaitu pelaporan laba atau rugi sebagai indikator good news atau bad news atas kinerja manajerial perusahaan dalam setahun.

Kantor Akuntan Publik (KAP) adalah lembaga yang memiliki izin dari Menteri Keuangan sebagai wadah bagi akuntan publik dalam menjalankan pekerjaannya. Pengukuran KAP dibagi menjadi dua yaitu KAP The Big Four dan KAP Non The Big Four. Menurut Dewi (2013:6) perusahaan yang menggunakan jasa KAP The Big Four diyakini dapat menyelesaikan auditnya lebih cepat dibanding KAP The Big Fourdemi mempertahankan reputasi dan kliennya serta dapat diartikan kualitas audit yang dihasilkan pun lebih baik karena didukung oleh kualitas dan kuantitas sumber daya manusia yang lebih baik sehingga akan berpengaruh pada kualitas jasa yang dihasilkan.

Menurut Lait et. all (2005) dalam Meihendri (2014:3) pergantian auditor secara umum dapat didefinisikan sebagai pergantian KAP dan penggantian auditor dalam rentang waktu tertentu dalam melakukan audit terhadap klien yang sama. Pembatasan masa pemberian jasa akuntan publik di Indonesia diatur melalui Peraturan Menteri Keuangan Republik Indonesia No: 17/PMK.01/2008, dalam ketentuan tersebut dinyatakan bahwa pelaksanaan jasa audit umum atas laporan keuangan untuk klien yang sama oleh KAP paling lama penugasan untuk 6 (enam) tahun berturu- 
turut dan seorang akuntan publik paling lama penugasan untuk 3 (tiga) tahun berturut-turut. Lebih lanjut dalam ketentuan tersebut, dinyatakan bahwa jasa audit umum atas laporan keuangan dapat diberikan kembali kepada klien yang sama melalui KAP setelah 1 (satu) tahun buku tidak memberikan jasa audit umum atas laporan keuangan klien tersebut.

Menurut Islahuzzaman (2012:292) opini audit adalah pendapat auditor tentang laporan keuangan yang telah diauditnya. Menurut Mulyadi (2002:20-22) ada lima opini auditor yang terdiri dari: pendapat wajar tanpa pengecualian (unqualified opinion), pendapat wajar tanpa pengecualian dengan tambahan penjelasan (unqualified opinion report with explanatory language), pendapat wajar dengan pengecualian (qualified opinion), pendapat tidak wajar (adverse opinion), dan pernyataan tidak memberikan pendapat (diclaimer opinion).

Penelitian ini bertujuan untuk menganalisis Faktor-faktor yang berpengaruh terhadap Audit Delay pada Basic Industry and Chemicals yang terdaftar di Bursa Efek Indonesia tahun 2013-2016.

\section{TINJAUAN PUSTAKA DAN HIPOTESIS}

\section{Teori Sinyal (Signalling Theory)}

Teori sinyal berakar pada teori akuntansi pragmatik yang memusatkan perhatiannya kepada pengaruh informasi terhadap perubahan perilaku pemakai informasi. Salah satu informasi yang dapat dijadikan sinyal adalah pengumuman yang dilakukan oleh suatu emiten. Pengumuman ini nantinya dapat mempengaruhi naik turunnya harga sekuritas perusahaan emiten yang melakukan pengumuman, Widosari (2012:14).

Manajer melakukan publikasi laporan keuangan untuk memberikan informasi kepada pasar. Umumnya pasar akan merespon informasi tersebut sebagai suatu sinyal good news atau bad news. Sinyal yang diberikan akan mempengaruhi pasar saham khususnya harga saham perusahaan. Jika sinyal manajemen mengindikasikan good news, maka dapat meningkatkan harga saham. Namun sebaliknya, jika sinyal manajemen mengindikasikan bad news dapat mengakibatkan penurunan harga saham perusahaan. Oleh karena itu, sinyal dari perusahaan merupakan hal yang penting bagi investor guna pengambilan keputusan.

Manfaat utama teori ini adalah akurasi dan ketepatan waktu penyajian laporan keuangan ke publik adalah sinyal dari perusahaan akan adanya informasi yang bermanfaat dalam kebutuhan untuk pembuatan keputusan dari investor. Semakin panjang audit delay menyebabkan 
ketidakpastian pergerakan harga saham. Investor dapat mengartikan lamanya audit delay dikarenakan perusahaan memiliki bad news sehingga tidak segera mempublikasikan laporan keuangannya, yang kemudian akan berakibat pada penurunan harga saham perusahaan.

\section{Teori Kepatuhan (Compliance Theory)}

Teori kepatuhan dapat mendorong seseorang untuk lebih mematuhi peraturan yang berlaku, sama halnya dengan perusahaan yang berusaha untuk menyampaikan laporan keuangan secara tepat waktu karena selain merupakan suatu kewajiban perusahaan untuk menyampaikan laporan keuangan tepat waktu, juga akan sangat bermanfaat bagi para pengguna laporan keuangan.

Seorang individu cenderung mematuhi hukum yang mereka anggap sesuai dan konsisten dengan norma-norma internal mereka. Komitmen normatif melalui moralitas personal (normative commitment through morality) berarti mematuhi peraturan karena otoritas penyususn hukum tersebut memiliki hak untuk mendikte perilaku, Sulistyo (2010) dalam Widosari (2012:17)

Teori kepatuhan dapat mendorong seseorang untuk lebih mematuhi peraturan yang berlaku, sama halnya dengan perusahaan yang berusaha untuk menyampaikan laporan keuangan secara tepat waktu karena selain merupakan suatu kewajiban perusahaan untuk menyampaikan laporan keuangan tepat waktu, juga akan sangat bermanfaat bagi para pengguna laporan keuangan, Dewi (2013:12).

\section{Audit Delay}

Ketepatan waktu (timeless) merupakan hal yang sangat penting dalam penerbitan laporan keuangan oleh perusahaan publik. Jangka waktu antara tanggal laporan keuangan dengan laporan audit (biasanya disebut audit delay) mencerminkan timeless dari penyampaian laporan keuangan publik. Menurut Ashton et. all (1987) dalam Kartika (2011:155), audit delay adalah lamanya waktu penyelesaian audit dari akhir tahun fiskal perusahaan sampai tanggal laporan audit dikeluarkan.

Menurut Abdula (1996) dalam Kartika (2011:155), semakin panjang waktu yang dibutuhkan di dalam mempublikasikan laporan keuangan tahunan sejak akhir tahun buku suatu perusahaan milik klien, maka semakin besar pula kemungkinan informasi tersebut bocor kepada investor tertentu atau bahkan bisa menyebabkan insider trading dan rumor-rumor lain di bursa saham. Apabila hal ini sering terjadi maka akan mengarahkan pasar tidak dapat lagi bekerja dengan maksimal. Dengan demikian regulator harus menentukan 
suatu regulasi yang dapat mengatur batas waktu penerbitan laporan keuangan yang harus dipenuhi pihak emiten. Tujuannya untuk tetap menjaga reliabilitas dan relevansi suatu informasi yang dibutuhkan oleh pihak pelaku bisnis di pasar modal. Waktu penyelesaian dapat diukur dari jumlah hari. Jumlah hari tersebut dapat dihitung dari tanggal penutupan tahun buku perusahaan dikurangi tanggal penerbitan laporan keuangan sehingga tampak seperti rumus berikut:

Audit delay $=$ tanggal laporan audit - tanggal laporan keuangan

\section{Ukuran Perusahaan}

Saemargani (2015:2) Ukuran perusahaan adalah besar kecilnya suatu perusahaan yang dilihat dari besar assetnya yang dimiliki oleh perusahaan tersebut. Ukuran perusahaan ditandai dengan beberapa ukuran antara lain, total penjualan, total asset, log size, jumlah pegawai, nilai pasar perusahaan, dan nilai buku perusahaan. Penelitian ini menggunakan logaritma natural yang dimiliki perusahaan sebagai ukuran perusahaan.

\section{Laba/Rugi Perusahaan}

Menurut Islahuzzaman (2012:244), laporan laba/rugi (income statement) adalah laporan yang menyajikan informasi tentang hasil usaha perusahaan selama periode tertentu. Dalam penelitian ini, perusahaan yang mengalami laba disebut good news dan perusahaan yang mengalami rugi disebut bad news.

\section{Ukuran KAP}

Menurut SK. Menkeu No. 43/KMK.017/1997 tertanggal 27 Januari 1997 sebagaimana telah diubah dengan SK. Menkeu N0.470/KMK.017/1999 tertanggal 4 Oktober 1999, Kantor Akuntan Publik (KAP) adalah lembaga yang memiliki izin dari Menteri Keuangan sebagai wadah bagi Akuntan Publik dalam menjalankan pekerjaanya.Dalam penelitian ini, KAP dibagi menjadi dua yaitu KAP The Big Four dan KAP Non The Big Four.

\section{Pergantian Auditor}

Menurut Lai et. all (2005) dalam Meihendri (2014:3) pergantian auditor secara umum dapat didefinisikan sebagai penggantian kantor akuntan publik dan penggantian auditor dalam rentang waktu tertentu dalam melalukan audit terhadap klien yang sama. Lebih lanjut menurut Lia et. all (2005) pergantian auditor merupakan salah satu rekomendasi dalam 
menyikapi berbagai skandal akuntansi yang terjadi disebabkan oleh lamanya keterkaitan akuntan dengan kliennya.

Peraturan Menteri Keuangan Republik Indonesia No: 17/PMK.01/2008, dalam ketentuan tersebut dinyatakan bahwa pelaksanaan jasa audit umum atas laporan keuangan untuk klien yang sama oleh KAP paling lama penugasan untuk 6 (enam) tahun berturu-turut dan seorang akuntan publik paling lama penugasan untuk 3 (tiga) tahun berturut-turut. Lebih lanjut dalam ketentuan tersebut, dinyatakan bahwa jasa audit umum atas laporan keuangan dapat diberikan kembali kepada klien yang samamelalui KAP setelah 1 (satu) tahun buku tidak memberikan jasa audit umum atas laporan keuangan klien tersebut.

\section{Opini Audit}

Menurut Islahuzzaman (2012:292) opini audit adalah pendapat auditor tentang laporan keuangan yang telah diauditnya. Pendapat auditor sangatlah penting bagi perusahaan ataupun pihak-pihak lain yang membutuhkan hasil dari laporan keuangan auditor. Menurut Mulyadi (2002:20-22) ada lima tipe pendapat laporan audit yang diterbitkan oleh auditor, yaitu:

1. Pendapat Wajar tanpa Pengecualian (Unqualified Opinion)

2. Pendapat Wajar tanpa Pengecualian dengan Bahasa Penjelasan

(Unqulified Opinion Report with Explanatory Language)

3. Pendapat Wajar dengan Pengecualian (Qualified Opinion)

4. Pendapat tidak Wajar (Adverse Opinion)

5. Tidak Memberikan Pendapat (Disclaimer of Opinion)

\section{Pengaruh Ukuran Perusahaan terhadap Audit Delay}

Menurut Saemargani (2015:2), ukuran perusahaan adalah besar kecilnya suatu perusahaan yang dilihat dari besarnya aset atau kekayaan yang dimiliki oleh perusahaan tersebut. Semakin besar ukuran perusahaan maka semakin baik pengendalian internal perusahaan sehingga dapat mengurangi tingkat kesalahan dalam penyajian laporan keuangan yang memudahkan auditor dalam melakukan pengauditan laporan keuangan tersebut sehingga mengalami audit delay yang lebih cepat atau singkat.

\section{Pengaruh Laba/Rugi Perusahaan terhadap Audit Delay}

Perusahaan yang mengalami laba disebut good news dan perusahaan yang mengalami rugi disebut bad news. Perusahaan yang mendapat laba tidak ada alasan untuk menunda penerbitan laporan 
keuangan auditan karena ini merupakan kabar baik, yaitu prestasi yang dicapai cukup menggembirakan sehingga menyebabkan audit delay semakin singkat. Sebaliknya, perusahaan yang mengalami kerugian akan meminta auditor untuk mengatur waktu auditnya lebih lama dibanding biasanya untuk mengumpulkan bukti-bukti penyebab terjadinya kerugian sehingga menyebabkan audit delay semakin lama.

\section{Pengaruh Ukuran KAP terhadap Audit Delay}

Ukuran KAP dalam dibagi menjadi dua yaitu KAP The Big Four dan KAP Non The Big Four. Perusahaan yang menggunakan jasa KAP The Big Four diyakini dapat menyelesaikan proses auditnya lebih cepat dibanding perusahaan yang menggunakan jasa KAP Non The Big Four demi mempertahankan reputasi dan kliennya serta dapat diartikan kualitas audit yang dihasilkan pun lebih baik karena didukung oleh kualitas dan kuantitas sumber daya manusia yang lebih baik sehingga akan berpengaruh pada kualitas jasa yang dihasilkan.

\section{Pengaruh Pergantian Auditor terhadap Audit Delay}

Pembatasan masa pemberian jasa akuntan publik di Indonesia diatur dalam Peraturan Menteri Keuangan Republik Indonesia No. 17/PMK.01/2008. Perusahaan yang mengalami pergantian auditor tentunya auditor baru membutuhkan waktu yang cukup lama untuk mengenali karakteristik usaha klien dan sistem yang ada didalamnya sehingga hal ini menyita waktu auditor dalam melaksanakan proses auditnya yang menyebabkan audit delay semakin lama.

\section{Pengaruh Opini Audit terhadap Audit Delay}

Perusahaan yang mendapat opini selain wajar tanpa pengecualian akan mengalami audit delay yang lebih lamakarena proses pemberian pendapat selain wajar tanpa pengecualian melibatkan negosiasi dengan klien, konsultasi dengan partner audit yang lebih senior atau staf teknis dan perluasan lingkup audit. Sedangkan perusahaan yang mendapat opini wajar tanpa pengecualian akan mengalami audit delay yang lebih singkat karena merupakan suatu berita baik bagi perusahaan untuk disampaikan sesegera mungkin kepada investor dan pihak yang berkepentingan. 


\section{Kerangka Berpikir}

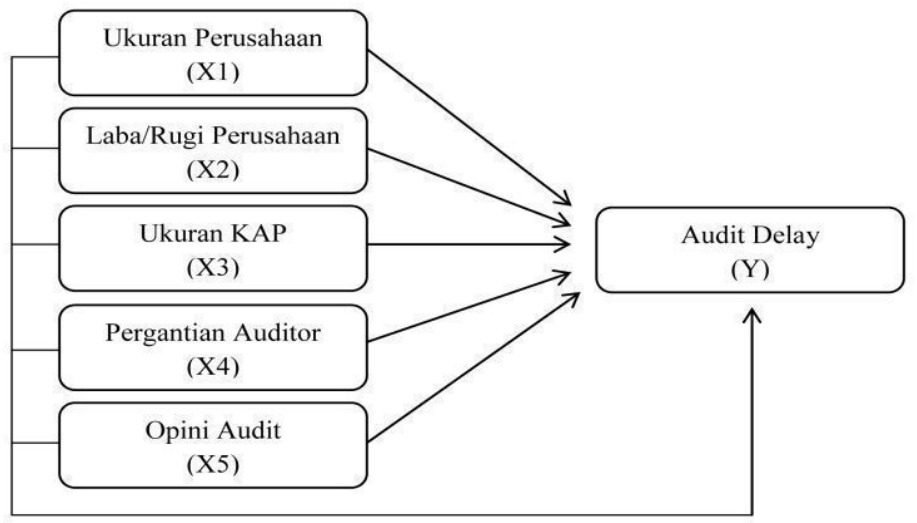

\section{Hipotesis}

Menurut Sugiyono (2015:85), hipotesis merupakan jawaban sementara atas permasalahan dalam objek penelitian. Berdasarkan perumusan masalah, maka hipotesis penelitian ini adalah:

H1 Ukuran Perusahaan berpengaruh terhadap Audit Delay pada Basic Industry and Chemicals yang terdaftar di Bursa Efek Indonesia.

H2 Laba/Rugi Perusahaan berpengaruh terhadap Audit Delay pada Basic Industry and Chemicals yang terdaftar di Bursa Efek Indonesia.

H3 Ukuran KAP berpengaruh terhadap Audit Delay pada Basic Industry and Chemicals yang terdaftar di Bursa Efek Indonesia.

H4 Pergantian Auditor berpengaruh terhadap Audit Delay pada Basic Industry and Chemicals yang terdaftar di Bursa Efek Indonesia.

H5 Opini Audit berpengaruh terhadap Audit Delay pada Basic Industry and Chemicals yang terdaftar di Bursa Efek Indonesia.

H6 Ukuran Perusahaan, Laba/Rugi Perusahaan, Ukuran KAP, Pergantian Auditor, dan Opini Audit secara simultan berpengaruh terhadap Audit Delay pada Basic Industry and Chemicals yang terdaftar di Bursa Efek Indonesia.

\section{METODE PENELITIAN}

\section{Populasi dan Sampel}

Populasi yang digunakan dalam penelitian ini adalah perusahaan manufaktur sektor Basic Industry and Chemicals yang terdaftar di Bursa Efek Indonesia tahun 2013-2016. 
Sampel penelitian dipilih dengan metode purposive sampling yaitu pemilihan sampel secara tidak acak yang informasinya diperoleh dengan menggunakan pertimbangan tertentu disesuaikan dengan tujuan atau masalah penelitian. Berdasarkan kreteria pemilihan sampel, jumlah sampel penelitian berjumlah 33 perusahaan.

\section{Operasionalisasi Variabel Audit Delay}

Audit Delay yaitu lamanya waktu penyelesaian audit yang diukur dari tanggal penutupan tahun buku hingga tanggal ditandatanganinya laporan audit. Tampak seperti rumus berikut:

Audit Delay $=$ tanggal laporan audit - tanggal laporan keuangan

\section{Ukuran Perusahaan}

Ukuran perusahaan adalah besar kecilnya suatu perusahaan yang dilihat dari besarnya aset atau kekayaan yang dimiliki oleh perusahaan tersebut. Dalam penelitian ini, pengukuran terhadap ukuran pperusahaan diproksikan dengan nilai logaritma natural dengan tujuan untuk menghaluskan besarnya angka dan menyamakan ukuran saat regresi.

\section{Laba/Rugi Perusahaan}

Ukuran Perusahaan $=$ Ln (total asset)

Laporan Laba/Rugi Perusahaan (income statement) adalah laporan yang menyajikan ukuran keberhasilan operasi perusahaan selama periode waktu tertentu. Dalam penelitian ini, laba/rugi perusahaan diukur dengan dummy yaitu untuk perusahaan yang mengalami laba diberi kode dummy 1 dan yang mengalami rugi diberi kode dummy 0 .

\section{Ukuran KAP}

Pada penelitian ini Ukuran KAP diukur dengan melihat KAP mana yang mengaudit laporan keuangan perusahaan. Ukuran KAP dalam penelitian ini diklasifikasikan menjadi dua yaitu perusahaan yang menggunakan jasa KAP the big four diberi kode 1 dan perusahaan yang tidak menggunakan jasa KAP non the big four diberi kode 0 .

\section{Pergantian Auditor}

Pada penelitian ini Pergantian Auditor diukur dengan melihat perusahaan yang melakukan pergantian auditor. Untuk perusahaan yang melakukan pergantian audior dibero kode 1 dan perusah 


\section{Opini Audit}

Opini Auditor adalah pendapat yang diberikan oleh auditor independen atas laporan keuangan yang disajikan oleh suatu perusahaan.Dalam penelitian ini pendapat auditor dibedakan menjadi dua kelompok yaitu perusahaan yang menerima pendapat unqualified opinion diberi kode 1 dan perusahaan yang menerima pendapat selain unqualified opinion diberi kode 0 .

\section{Teknik Analisis Data}

Pada penelitian ini, pengujian dilakukan dengan analisis regresi linear berganda (multiple linier regression). Adapun model regresi linier berganda dalam penelitian ini adalah sebagai berikut:

$$
\mathrm{Y}=\alpha+\beta 1 \mathrm{X} 1+\beta 2 \mathrm{X} 2+\beta 3 \mathrm{X} 3+\beta 4 \mathrm{X} 4+\beta 5 \mathrm{X} 5+\varepsilon
$$

Keterangan:

$\mathrm{Y}=$ Audit Delay

$\alpha=$ Konstanta

$\beta 1, \beta 2, \beta 3, \beta 4, \beta 5=$ Koefisien regresi

$\mathrm{X} 1=$ Ukuran Perusahaan

$\mathrm{X} 2$ = Laba/rugi Perusahaan

X3 = Ukuran KAP

X4 = Pergantian Auditor

X5 = Opini Audit

$\varepsilon=$ Faktor Pengganggu

\section{HASIL PENELITIAN DAN PEMBAHASAN}

\section{Uji Asumsi Klasik}

\section{Uji Normalitas}

Uji normalitas bertujuan untuk menguji apakah dalam model regresi, variabel dependen dan variabel independen berdistribusi normal. Uji normalitas dapat dilakukan dengan analisis grafik. Pada grafik histogram, data yang mengikuti atau mendekati distribusi normal adalah distribusi data dengan bentuk lonceng. Berikut hasil uji normalitas dengan menggunakan analisis grafik. 


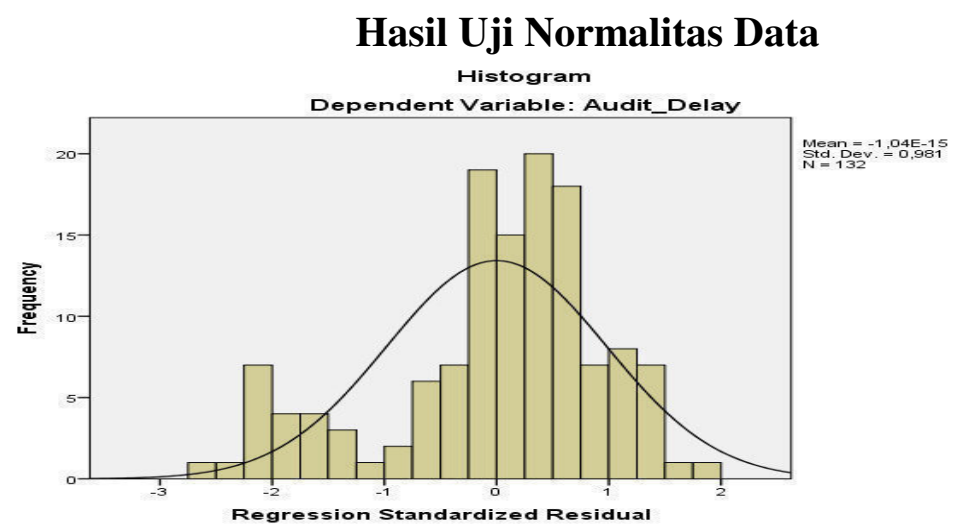

Sumber : Hasil Output SPSS 23 (Data diolah)

Berdasarkan grafik histogram tersebut dapat dilihat bahwa data telah terdistribusi normal.

\section{Uji Multikolinearitas}

Model regresi yang baik seharusnya tidak terjadi korelasi diantara variabel independennya. Metode untuk menguji adanya multikolinearitas dapat dilihat pada tolerance value atau variance inflammatory factor (VIF). Batas tolerance value adalah 0,10 atau nilai VIF adalah 10. Jika VIF $>10$ dan nilai Tolerance $<0.10$, maka tejadi multikolinearitas tinggi antar variabel bebas dengan variable bebas lainnya.

\section{Coefficients $^{\mathrm{a}}$}

\section{Hasil Uji Multikolinearitas}

\begin{tabular}{|l|r|r|r|r|r|}
\hline \multirow{2}{*}{ Model } & \multicolumn{2}{|c|}{$\begin{array}{c}\text { Unstandardized } \\
\text { Coefficients }\end{array}$} & \multicolumn{2}{c|}{$\begin{array}{c}\text { Standardized } \\
\text { Coefficients }\end{array}$} & \multicolumn{2}{c|}{ Collinearity Statistics } \\
\cline { 2 - 7 } & \multicolumn{1}{c|}{ B } & Std. Error & \multicolumn{1}{c|}{ Beta } & Tolerance & VIF \\
\hline $1 \quad$ (Constant) & 8,778 & 1,326 & & & \\
& $-1,333$ &, 400 &,- 373 &, 542 & 1,844 \\
Ukuran_Perusahaan &,- 090 &, 037 &,- 221 &, 827 & 1,210 \\
Laba Rugi Perusahaan &, 094 &, 045 &, 235 &, 542 & 1,844 \\
Ukuran KAP &, 004 &, 051 &, 008 &, 765 & 1,307 \\
Pergantian Auditor &, 046 &, 036 &, 122 &, 754 & 1,327 \\
Opini Audit & & &
\end{tabular}

a. Dependent Variable: Audit Delay

Sumber : Hasil Output SPSS 23 (Data diolah)

Dari tabel coefficients dapat diketahui bahwa nilai Tolerance dari ke empat variabel independen lebih dari 0,1 dan VIF kurang dari 10. Jadi penelitian ini bebas dari adanya multikolonieritas. 


\section{Uji Autokorelasi}

Autokorelasi menunjukkan adanya korelasi antara kesalahan pengganggu pada periode $\mathrm{t}$ dengan kesalahan pada periode $\mathrm{t}-1$. Untuk mengetahui adanya autokorelasi dalam suatu model regresi, dilakukan pengujian Durbin-Waston.

\section{Hasil Uji Autokorelasi}

Model Summary

\begin{tabular}{|l|r|r|r|r|r|}
\hline Model & $\mathrm{R}$ & R Square & $\begin{array}{c}\text { Adjusted R } \\
\text { Square }\end{array}$ & $\begin{array}{c}\text { Std. Error of the } \\
\text { Estimate }\end{array}$ & Durbin-Watson \\
\hline 1 &, $378^{\mathrm{a}}$ &, 143 &, 109 &, 17103 & 2,071 \\
\hline
\end{tabular}

a. Predictors: (Constant), Opini Audit, Ukuran_Perusahaan, Laba Rugi Perusahaan, Pergantian Auditor, Ukuran KAP

b. Dependent Variable: Audit_Delay

Sumber :Hasil Output SPSS 23 (Data diolah)

Berdasarkan data pada penelitian ini, nilai DW (Durbin Waston) adalah 2,071 Nilai dL dan dU diambil dari tabel Durbin Waston pada signifikansi $0,05, \mathrm{n}=132$ dan $\mathrm{k}=5$ di dapat $\mathrm{dL}$ 1,6380 dan $\mathrm{dU}$ 1,7950. Dapat diketahui bahwa nilai Dw (Durbin-Waston) sebesar 2,071 terletak pada daerah $\mathrm{dU}<\mathrm{dw}<4-\mathrm{dU}(1,7950<2,071<2,205)$ maka kesimpulannya tidak terjadi autokorelasi pada model penelitian ini.

\section{Uji Heteroskedastisitas}

Heteroskedastisitas adalah keadaan dimana terjadinya ketidaksamaan dari residual pada model regresi. Model regresi yang baik adalah homokedastisitas, yaitu varian dan residual satu pengamatan ke pengamatan yang lain hasilnya tetap. Dalam penelitian ini digunakan diagram titik (scatterplot). Jika titik-titik menyebar dengan pola yang tidak jelas diatas dan dibawah angka 0 pada sumbu Y maka tidak terjadi masalah heteroskedastisitas. Scatterplotdapat dilihat pada output regresi dan disajikan sebagai berikut:

\section{Hasil Uji Heteroskedastisitas}

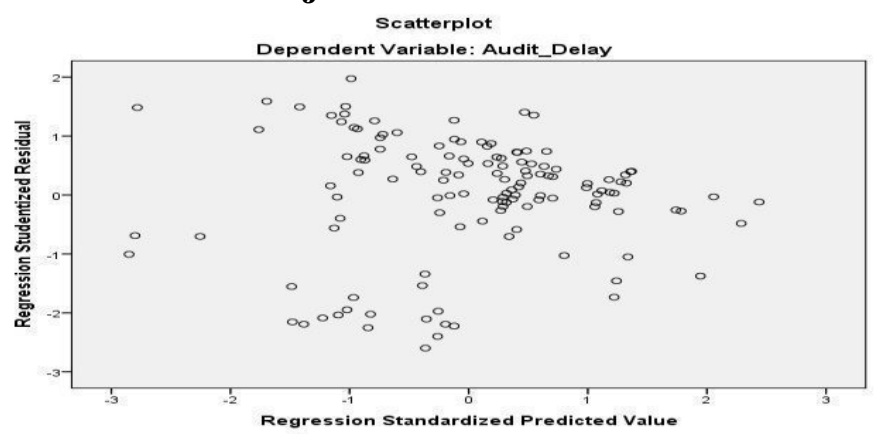

Sumber : Hasil Output SPSS 23 (Data diolah) 
Dari scatterplot tersebut dapat diketahui bahwa titik-titik menyebar dengan pola yang tidak jelas diatas dan dibawah angka 0 pada sumbu Y, maka pada model regresi ini tidak terjadi masalah heteroskedastisitas.

\section{Analisis Regresi Linier Berganda}

Pada penelitian ini, pengujian dilakukan dengan analisis linear berganda, yaitu suatu metode statistik yang umum digunakan untuk meneliti hubungan antara sebuah variabel dependen dengan variabel independen.

\section{Hasil Analisis Regresi Linier Berganda}

Coefficients $^{\mathrm{a}}$

\begin{tabular}{|c|c|c|c|c|c|}
\hline \multirow[b]{2}{*}{ Model } & \multicolumn{2}{|c|}{$\begin{array}{c}\text { Unstandardized } \\
\text { Coefficients }\end{array}$} & \multirow{2}{*}{$\begin{array}{c}\begin{array}{c}\text { Standardized } \\
\text { Coefficients }\end{array} \\
\text { Beta }\end{array}$} & \multirow[b]{2}{*}{ I } & \multirow[b]{2}{*}{ Sig. } \\
\hline & $\mathrm{B}$ & Std. Error & & & \\
\hline (Constant) & 8,778 & 1,326 & & 6,620 &, 000 \\
\hline Ukuran_Perusahaan & $-1,333$ & ,400 &,- 373 & $-3,330$ & ,001 \\
\hline Laba Rugi Perusahaan &,- 090 & ,037 &,- 221 & $-2,435$ &, 016 \\
\hline Ukuran KAP & ,094 & ,045 & 235 & 2,098 & ,038 \\
\hline Pergantian Auditor & ,004 & ,051 &, 008 & 087 & ,931 \\
\hline Opini Audit &, 046 & ,036 & ,122 & 1,283 & 202 \\
\hline
\end{tabular}

a. Dependent Variable: Audit_Delay

Sumber: Hasil Output SPSS 23 (Data diolah)

Berdasarkan tabel diatas, maka persamaan regresinya yaitu:

Audit Delay $=8,778-1,333 \mathrm{X} 1-0,090 \mathrm{X} 2+0.094 \mathrm{X} 3+0,004 \mathrm{X} 4+$ $0.046 \times 5+\varepsilon$

\section{Koefisien Determinasi $\left(\mathbf{R}^{2}\right)$}

Koefisien determinasi menunjukkan seberapa besar variabel independen dalam penelitian mampu menjelaskan variabel dependennya.

Model Summary ${ }^{\mathbf{b}}$ Hasil Uji Koefisien Determinasi $\left(\mathbf{R}^{\mathbf{2}}\right)$
\begin{tabular}{|l|c|r|r|r|}
\hline Model & $\mathrm{R}$ & R Square & $\begin{array}{c}\text { Adjusted R } \\
\text { Square }\end{array}$ & $\begin{array}{c}\text { Std. Error of the } \\
\text { Estimate }\end{array}$ \\
\hline 1 &, $378^{\mathrm{a}}$ &, 143 &, 109 &, 17103 \\
\hline
\end{tabular}

a. Predictors: (Constant), Opini Audit, Ukuran_Perusahaan, Laba Rugi Perusahaan,

Pergantian Auditor, Ukuran KAP

b. Dependent Variable: Audit_Delay

Sumber: Hasil Output SPSS 23 (Data diolah) 
Berdasarkan tabel diatas, nilai $\mathrm{R}$ Square atau $R^{2}$ yang diperoleh sebesar 0.143 ini berarti variabel bebas ukuran perusahaan, laba/rugi perusahaan, ukuran KAP, pergantian auditor dan opini audit secara bersama-sama mempengaruhi variabel dependen yaitu audit delay sebesar $14,3 \%$. Sedangkan $85,7 \%$ ditentukan oleh variabel lain yang tidak dibahas dalam penelitian ini.

\section{Uji Signifikansi Simultan (Uji F)}

Hasil Uji Signifikansi Simultan (Uji F) ANOVA $^{\mathrm{a}}$

\begin{tabular}{|ll|r|r|r|r|r|}
\hline Model & & Sum of Squares & \multicolumn{1}{c|}{ df } & Mean Square & F & Sig. \\
\hline 1 & Regression &, 615 & 5 &, 123 & 4,208 &, $001^{\mathrm{D}}$ \\
& Residual & 3,686 & 126 &, 029 & & \\
& Total & 4,301 & 131 & & & \\
\hline
\end{tabular}

a. Dependent Variable: Audit_Delay

b. Predictors: (Constant), Opini Audit, Ukuran_Perusahaan, Laba Rugi Perusahaan, Pergantian Auditor, Ukuran KAP

Sumber :Hasil Output SPSS 23 (Data diolah)

Berdasarkan hasil uji $\mathrm{F}$ pada tabel tersebut, nilai Fhitung 4,208 > F tabel 2,29 dan nilai signifikan $0,001<0,05$. Hal ini berarti bahwa variabel ukuran perusahaan, laba/rugi perusahaan, ukuran KAP, pergantian auditor dan opini audit secara simultan berpengaruh signifikan pada variabel dependen audit delay pada basic industry and chemicals yang terdaftar di Bursa Efek Indonesia (BEI).

Coefficients $^{a}$

\begin{tabular}{|c|c|c|c|c|c|}
\hline \multirow[b]{2}{*}{ Model } & \multicolumn{2}{|c|}{$\begin{array}{l}\text { Unstandardized } \\
\text { Coefficients }\end{array}$} & \multirow{2}{*}{$\begin{array}{c}\begin{array}{c}\text { Standardized } \\
\text { Coefficients }\end{array} \\
\text { Beta }\end{array}$} & \multirow[b]{2}{*}{$\mathrm{T}$} & \multirow[b]{2}{*}{ Sig. } \\
\hline & $\mathrm{B}$ & Std. Error & & & \\
\hline 1 (Constant) & 8,778 & 1,326 & & 6,620 &, 000 \\
\hline Ukuran_Perusahaan & $-1,333$ & ,400 &,- 373 & $-3,330$ & ,001 \\
\hline Laba Rugi Perusahaan &,- 090 & ,037 &,- 221 & $-2,435$ & ,016 \\
\hline Ukuran KAP & 094 & ,045 & ,235 & 2,098 & ,038 \\
\hline Pergantian Auditor & ,004 & ,051 & ,008 & ,087 & ,931 \\
\hline Opini Audit & ,046 & ,036 & ,122 & 1,283 & 202 \\
\hline
\end{tabular}

a. Dependent Variable: Audit_Delay

Sumber :Hasil Output SPSS 23 (Data diolah) 


\section{Uji Signifikansi Parsial (Uji t)}

\section{Hasil Uji Signifikansi Parsial (Uji t)}

Berdasarkan tabel di atas dapat dijelaskan beberapa hal sebagai berikut:

- Hipotesis 1: "Ukuran Perusahaan berpengaruh negatif dan signifikan terhadap Audit Delay". Dari tabel diatas dapat dilihat bahwa Ukuran Perusahaan memiliki t-hitung $-3,330>\mathrm{t}$-tabel 1,97897 pada sig 0,001 $<0,05$. Hal ini menunjukkan bahwa Ukuran Perusahaan berpengaruh negatif dan signifikan terhadap Audit Delay, dan kesimpulannya $\mathrm{H}_{1}$ diterima.

- Hipotesis 2: "Laba/Rugi Perusahaan berpengaruh negatif dan signifikan terhadap Audit Delay". Dari tabel diatas dapat dilihat bahwa Laba/Rugi perusahaan memiliki t-hitung -2,435 (karena daerah kritis tidak terpengaruhi oleh adanya nilai negatif) $>$ t-tabel 1,97897 pada sig $0,016<0,05$. Hal ini menunjukkan bahwa Laba/Rugi Perusahaan berpengaruh negatif dan signifikan terhadap Audit Delay, dan kesimpulannya $\mathrm{H}_{2}$ diterima.

- Hipotesis 3: "Ukuran KAP berpengaruh negatif dan signifikan terhadap Audit Delay". Dari tabel diatas dapat dilihat bahwa Ukuran KAP memiliki t-hitung 2,098> t-tabel 1,97897 pada sig 0,038>0,05. Hal ini menunjukkan bahwa Ukuran KAP berpengaruh positif dan signifikan terhadap Audit Delay, dan kesimpulannya $\mathrm{H}_{3}$ ditolak.

- Hipotesis 4: "Pergantian Auditor berpengaruh positif dan signifikan terhadap Audit Delay". Dari tabel diatas dapat dilihat bahwa Pergantian Auditor memiliki t-hitung 0,087> t-tabel 1,97897 pada sig $0,931>0,05$. Hal ini menunjukkan bahwa Ukuran KAPtidak berpengaruh secara signifikan terhadap Audit Delay, dan kesimpulannya $\mathrm{H}_{4}$ ditolak.

- Hipotesis 5: "Opini Audit berpengaruh negatif dan signifikan terhadap Audit Delay". Dari tabel diatas dapat dilihat bahwa Opini Audit memiliki t-hitung 1,283<t-tabel 1,97897 pada sig 0,202>0,05. Hal ini menunjukkan bahwa Opini Audittidak berpengaruh secara signifikan terhadap Audit Delay, dan kesimpulannya $\mathrm{H}_{5}$ ditolak. 


\section{PEMBAHASAN}

1. Pengaruh Ukuran Perusahaan terhadap Audit Delay

Ukuran Perusahaan memiliki t-hitung -3,330 > t-tabel 1,97897 pada sig 0,001 < 0,05. Hal ini menunjukkan bahwa Ukuran Perusahaan berpengaruh negatif dan signifikan terhadap Audit Delay, dan kesimpulannya $\mathbf{H}_{\mathbf{1}}$ diterima. Kekayaan yang dimiliki oleh perusahaan ternyata mempunyai pengaruh yang signifikan terhadap audit delay. Hal ini disebabkan semakin besar perusahaan, maka perusahaan tersebut memiliki pengendalian internal yang lebih baik sehingga dapat mengurangi tingkat kesalahan dalam penyajian laporan keuangan sehingga memudahkan auditor dalam melaksanakan proses pengauditan atas laporan keuangan perusahaan.

Hal ini sejalan dengan logika teori Givoli dan Palmon (1982) dalam Yulianti (2011:15) yang menyatakan bahwa perusahaan yang besar cenderung melaporkan laporan keuangannya lebih cepat dibandingkan dengan perusahaan kecil, yang berarti perusahaan besar akan membutuhkan rentang waktu pemeriksaan yang lebih pendek dibandingkan dengan perusahaan kecil dan perusahaan besar cenderung berada dibawah tekanan karena lebih diawasi oleh BAPEPAM, investor dan calon investor.

\section{Pengaruh Laba/Rugi Perusahaan terhadap Audit Delay}

Laba/Rugi perusahaan memiliki t-hitung -2,435 > t-tabel 1,97897 pada sig $0,016<0,05$. Hal ini menunjukkan bahwa Laba/Rugi Perusahaan berpengaruh negatif dan signifikan terhadap Audit Delay, dan kesimpulannya $\mathbf{H}_{2}$ diterima. Perusahaan yang mengalami rugi ingin menunda bad news sehingga akan meminta auditor untuk menjadwal ulang penugasan audit dan auditor akan lebih berhati-hati selama proses audit dalam merespon kerugian perusahaan.

Hal ini sejalan dengan logika teori Kartika (2011:162) yang menyatakan bahwa perusahaan yang mendapatkan laba yang besar tidak ada alasan untuk menunda penerbitan laporan keuangan auditan bahkan cenderung untuk mempercepat penerbitan laporan keuangan auditan, karena perusahaan yang mengalami laba akan membuat investor menjadi 
senang dan calon investor akan tertarik untuk membeli saham sehingga akan menyebabkan kenaikan harga saham.

Hasil penelitian ini juga sejalan dengan teori Iskandar dan Trisnawati (2010:184) yang menyatakan bahwa perusahaan yang menderita kerugian akan meminta auditornya untuk menjadwalkan kembali pengauditan lebih lambat dari biasanya sehingga menunda untuk mengumumkan "bad news" kepada publik. Auditor juga cenderung berhati-hati dalam prosedur-prosedur audit yang dapat memastikan nilai kerugian sehingga dengan demikian proses audit akan lebih panjang yang menyebabkan audit delay semakin lama.

\section{Pengaruh Ukuran KAP terhadap Audit Delay}

Ukuran KAP memiliki t-hitung 2,098 > t-tabel 1,97897 pada sig $0,038>0,05$. Hal ini menunjukkan bahwa Ukuran KAP berpengaruh positif dan signifikan terhadap Audit Delay, dan kesimpulannya $\mathbf{H}_{\mathbf{3}}$ ditolak.

Hasil penelitian ini menolak logika teori Yulianti (2011:78) yang menyatakan bahwa ukuran KAP the big four cenderung lebih cepat menyelesaikan tugas audit yang mereka terima dan mengeluarkan pendapat yang sewajarnya. Hal ini dikarenakan KAP yang masuk the big four dengan yang non the big four memiliki karakteristik yang berbeda. KAP the big four akan bekerja lebih efektif dan efisien sehingga akan lebihcepat dalam penyampaian laporan auditan. KAP Internasional (the big four) dapat melaksanakan auditnya secara efisien dan memperoleh insentif yang tinggi untuk menyelesaikan audit delay nya lebih cepat dibanding KAP yang lain. The big four cenderung menyajikan audit yang lebih cepat dibandingkan non the big four karena mereka memiliki nama baik yang dipertaruhkan. KAP the big four umumnya mempunyai sumber daya yang lebih besar sehingga dapat melakukan audit lebih cepat dan efisien.

Hasil penelitian ini mendukung hasil penelitian yang dilakukan oleh Saemargani (2015) yang menyatakan bahwa ukuran KAP berpengaruh positf dan signifikan terhadap audit delay, dan menolak hasil penelitian yang dilakukan oleh Kartika (2011) yang menyatakan bahwa ukuran KAP tidak berpengaruh terhadap audit delay.

\section{Pengaruh Pergantian Auditor terhadap Audit Delay}

Pergantian Auditor memiliki t-hitung 0,087 > t-tabel 1,97897 pada sig 0,931 > 0,05. Hal ini menunjukkan bahwa Ukuran KAP tidak berpengaruh secara signifikan terhadap Audit Delay, dan kesimpulannya 
$\mathbf{H}_{\mathbf{4}}$ ditolak. Pada kenyataannya tidak semua perusahaan yang melakukan pergantian auditor mengalami audit delay yang lebih lama karena pergantian auditor bisa dilakukan jauh sebelum tahun tutup buku berakhir.

Hasil penelitian ini menolak logika teori Rustiarini dan Sugiarti (2009:663) bahwa perusahaan yang mengalami pergantian auditor, tentunya auditor baru membutuhkan waktu yang cukup lama untuk mengenali karakteristik usaha klien dan sistem yang ada didalamnya sehingga hal ini menyita waktu auditor dalam melaksanakan proses auditnya. Hasil penelitian ini sejalan dengan penelitian Widhiasari dan Budiartha (2016), dan menolak hasil penelitian yang dilakukan Rustiarini dan Sugiarti (2013).

\section{Pengaruh Opini Audit terhadap Audit Delay}

Opini Audit memiliki t-hitung 1,283< t-tabel 1,97897 pada sig $0,202>0,05$. Hal ini menunjukkan bahwa Opini Audittidak berpengaruh secara signifikan terhadap Audit Delay, dan kesimpulannya $\mathbf{H}_{5}$ ditolak. Opini audit tidak berpengaruh terhadap audit delay karena auditor sudah bekerja secara profesional. Selain itu, untuk menentukan kewajaran dan mengeluarkan opini wajar tanpa pengecualian, seorang auditor tentu harus mengumpulkan bukti-bukti yang lengkap dan akurat sehingga proses pengauditan atas laporan keuangan klien tentunya membutuhkan waktu yang cukup lama.

Hasil penelitian ini menolak logika teori Yuana (2008:15) dalam Yulianti (2011:17) yang menyatakan bahwa perusahaan yang mendapat opini Wajar Tanpa Pengecualian mengalami audit delayyang lebih singkat karena selama pelaksanaan pekerjaan lapangan auditor tidak menemukan masalah ataupun bukti yang sangat menyimpang sesuai dengan akuntansi yang berterima umum maka auditor dapat dengan cepat menyelesaikan tugasnya dengan cepat dibandingkan perusahaan yang mendapat opini selain Wajar Tanpa Pengecualian karena perusahaan perusahaan menemukan penyimpangan dalam laporan keuangan tidak sesuai dengan prinsip akuntansi berterima umum sehingga membuat auditor lebih banyak lagi mencari penyimpangan serta bukti-bukti lain yang menyebabkan audit delay semakin lama. 
Hal ini sejalan dengan hasil penelitian Kartika (2011) yang menyatakan bahwa opini audit tidak berpengaruh terhadap audit delay dan menolak hasil penelitian Widosari (2012).

\section{KESIMPULAN DAN SARAN}

\section{Kesimpulan}

Berdasarkan hasil penelitian dan pembahasan Maka diperoleh kesimpulan sebagai berikut:

1. Ukuran Perusahaan secara parsial berpengaruh negatif dan signifikan terhadap Audit Delay.

2. Laba/Rugi Perusahaan secara parsial berpengaruh negatif dan signifikan terhadap Audit Delay.

3. Ukuran (KAP) secara parsial berpengaruh positif dan signifikan terhadap Audit Delay.

4. Pergantian Auditor secara parsial tidak berpengaruh signifikan terhadap Audit Delay.

5. Opini Audit secara parsial tidak berpengaruh signifikan terhadap Audit Delay.

6. Ukuran Perusahaan, Laba/Rugi Perusahaan, Ukuran KAP, Pergantian Auditor, dan Opini Audit berpengaruh signifikan secara simultan terhadap Audit Delay.

\section{Saran}

Adapun saran-saran yang dapat penulis berikan sehubungan dengan keterbatasan yang terdapat dalam penelitian ini adalah sebagai berikut:

1. Peneliti selanjutnya diharapkan menggunakan variabel-variabel lain yang kemungkinan dapat mempengaruhi audit delay.

2. Sebaiknya lebih memperpanjang periode pengamatan dalam penelitiannya agar diperoleh data yang lebih valid dan lebih lengkap.

3. Penelitian selanjutnya juga dapat menggunakan alat uji selain regresi linear berganda. 


\section{DAFTAR PUSTAKA}

Apriliane, Malinda Dwi. 2015. Analisis Faktor-Faktor Yang Mempengaruhi Audit Delay ( Studi Empiris Pada Perusahaan Pertambangan yang Terdaftar di BEI Tahun 2008-2013).Skripsi. Yogyakarta: Universitas Negeri Yogyakarta.

Ariyanti, Rizki. 2017. Faktor-Faktor Yang Berpengaruh Terhadap Audi Delay Pada Perusahaan Liquid 45. Jurnal. Surabaya: Sekolah Tinggi Ilmu Ekonomi Indonesia.

BAPEPAM LK.2003. Keputusan Ketua Badan Pengawas Pasar Modal dan Lembaga Keuangan Nomor: KEP-36/PMK/2003.

.2004. Keputusan Direksi PT Bursa Efek Jakarta Nomor:307/BEJ/07-2004.

Brigham F Eugene, Houston F Joel. 2006. Dasar-Dasar Manajemen Keuangan. Jakarta: Salemba Empat.

Dewi, Karina Mutiara. Analisis Faktor-Faktor Yang Mempengaruhi Ketepatan Waktu Dan Audit Delay Penyampaian Laporan Keungan (Studi Empiris Pada Perusahaan Manufaktur Yang Terdaftar di BEI Tahun 2007-2011). Skripsi. Semarang: Universitas Diponegoro.

Divianto. 2011. Faktor-Faktor Yang Berpengaruh Terhadap Audit Delay Perusahaan Sektor Perdagangan Yang Terdaftar di BEI Periode 20072009.Jurnal. Palembang: Politeknik Negeri Sriwijaya.

Ghozali, Imam. 2016. Aplikasi Analisis Multivariate dengan Program SPSS Edisi 8. Semarang: Badan Penerbit Universitas Diponegoro.

Ikatan Akuntan Indonesia. 2009. Standar Akuntansi Keuangan. Jakarta: Salemba Empat. 2009. Standar Profesional Akuntan Publik. Jakarta: Salemba Empat.

Iskandar dan Trisnawati. 2010. Faktor-faktor yang Mempengaruhi Audit Delay pada Perusahaan Manufaktur yang Terdaftar di Bursa Efek Indonesia.Jurnal Bisnis dan Akuntansi Vol. 12. Jakarta: Universitas Tarumanegara.

Islahuzzaman. 2012. Istilah-Istilah Akuntansi dan Auditing. Jakarta: Bumi Aksara.

Kartika, Andi .2011. Faktor-faktor yang mempengaruhi Audit Delay : Pada perusahaan Manufaktur yang terdaftar di BEI. Jurnal Dinamika Keuangan dan Perbankan Vol. ISSN: 1979-4878. 
Lestari, Dewi. 2010. Analisis Faktor-faktor yang Mempengaruhi Audit Delay: Pada Perusahaan Consumer Goods yang terdaftar di BEI.Skripsi. Semarang: Universitas Diponegoro.

Meihendri. 2014. Pengaruh Pergantian Auditor dan Independensi Auditor Terhadap Kualitas Audit.Jurnal. Padang: Universitas Bung Hatta.

Menteri Keuangan. 1999. Peraturan Menteri Keuangan Nomor 470/KMK.017/1999.

2008. Peraturan Menteri Keuangan Nomor 12/PMK.01/2008 “Jasa Akuntan Publik” Jakarta.

Mulyadi. 2002. Auditing. Buku I Edisi keenam. Jakarta: Salemba Empat.

Pasopati, Giras. 2016, 30 Juni. Telat Sampaikan Lapkeu BEI Suspensi Saham 18 Perusahaan.CNN Indonesia.

Prasongkoputra Adinugraha. 2013. Faktor-Faktor Yang Mempengaruhi Audit Delay. Skripsi. Jakarta: Universitas Islam Negeri Syarif Hidayatullah.

Ristin, Fika. 2016. Faktor-faktor Yang Mempengaruhi Audit Delay Pada Perusahaan Manufaktur di Bursa Efek Indonesia Tahun 20122014.Skripsi. Makassar: Universitas Hasanuddin.

Rustiarini dan Sugiarti. 2013. Pengaruh Reputasi Auditor, Spesialisasi Auditor, Opini Audit, Audit Tenure, Pergantian Auditor Terhadap Audit Delay Pada Perusahaan Manufaktur yang terdaftar di BEI.Jurnal Ilmiah Akuntansi dan Humanika Vol.2. ISSN: 2089-3310.

Saemargani, Fitria Ingga. 2015. Pengaruh Ukuran Perusahaan, Umur Perusahaan, Profitabilitas Perusahaan, Solvabilitas Perusahaan, ukuran KAP dan Opini Auditor terhadap Audit delay (studi kasus pada perusahaan LQ45 yang terdaftar di Bursa Efek Indonesia tahun 20112013). Jurnal Nominal Vol. 4 No. 2. Yogyakarta: Universitas Negeri Yohyakarta.

Saputri, Dewi Oviek. 2012. Analisis Faktor-Faktor Yang Mempengaruhi Audit Delay (Stide Empiris Pada Perusahaan-Perusahaan Yang Terdaftar di Bursa Efek Indonesia). Skripsi. Semarang: Universitas Diponegoro.

Situmorang, Rapi. 2017. Faktor-faktor Yang Berpengaruh Terhadap Audit Delay pada Consumer Goods Industry Yang Terdaftar di Bursa Efek Indonesia Tahun 2013-2016.Skripsi. Medan: Universitas Katolik Santo Thomas Sumatera Utara.

Sugiyono. 2015. Statistik Untuk Penelitian. Bandung: Alfabeta. 
Sunaningsih, Suci Nasaehati. 2014. Faktor-faktor Yang Berpengaruh Terhadap Audit Delay (Studi Empiris pada Perusahaan Sektor Jasa yang Terdaftar di BEI Periode Tahun 2011-2012).Skripsi. Semarang: Universitas Diponegoro.

Sulistyo, Wahyu Adhy Noor. 2010. Analisis Faktor-Faktor Yang Berpengaruh Terhadap Ketepatan Waktu Penyampaian Laporan Keuangan Pada Perusahaan Yang Listing di Bursa Efek Indonesia Periode 2006-2008. Skripsi. Semarang: Universitas Diponegoro.

Tandiontong, Mathius. 2016. Kualitas Audit dan Pengukurannya. Bandung: Alfabeta.

Widosari, Shinta Altia. 2012. Analisis Faktor-faktor Yang Berpengaruh Terhadap Audit Delay Pada Perusahaan Manufaktur di Bursa Efek Indonesia Tahun 2008-2010.Skripsi. Semarang: Universitas Diponegoro.

Yulianti, Ani. 2011. Faktor-faktor Yang Berpengaruh Terhadap Audit Delay (Studi Empiris pada Perusahaan yang Terdaftar di Bursa Efek Indonesia Tahun 2007-2008). Skripsi. Yogyakarta: Universitas Negeri Yogyakarta. 